\title{
АНДРАГОГІЧНА МОДЕЛЬ НАВЧАННЯ ДОРОСЛИХ У СИСТЕМІ ПІСЛЯДИПЛОМНОЇ ОСВІТИ
}

\author{
О. М. Хвисюк, В. Г. Марченко, О. М. Касьянова, В. В. Жеребкін, І. А. Жадан, \\ К. І. Бодня, О. В. Грищенко, І. А. Соболсва, О. І. Сергієнко \\ Харківська медична академія післядипломноїосвіти
}

\section{THE ANDROGOGICAL MODEL OF THE STUDYING OF ADULTS IN THE SYSTEM OF POST-GRADUATE EDUCATION}

\author{
O. M. Khvysiuk, V. H. Marchenko, O. M. Kasyanova, V. V. Zherebkin, I. A. Zhadan, \\ K. I. Bodnya, O. V. Hryshchenko, I. A. Sobolieva, O. I. Serhiyenko \\ Kharkiv Medical Academy of Post-Graduate Education
}

У статті розглянуті особливості навчання дорослих у системі післядипломної освіти.

The article adduces the peculiarities of the studying of adults in the system of post-graduate education.

Вступ. Інтелектуалізація праці, швидка зміна технології та зростання соціальної ролі особистості вимагають від післядипломної освіти не лише вдосконалення професійної підготовки шляхом поглиблення, розширення й поповнення їх професійних знань, умінь на основі здобутого рівня, а й “...створення умов для задоволення освітніх та професійних потреб і надання можливості кожному громадянину України постійно вдосконалювати свою освіту, підвищувати професійний рівень, оволодівати новими спеціальностями" [1].

Відповідно до означених пріоритетів традиційне, одноразове, порівняно короткочасне, відносно однобічне навчання на циклах підвищення кваліфікації сьогодні не задовольняє ні суспільство, ні самого фахівця. Крім того, на думку С. І. Змєйова, “для задоволення цих різко зростаючих вимог традиційно сформовані системи освіти, достатньо замкнуті, негнучкі, певною мірою “кастові”, “закриті”, виявилися неготовими" [2]. Тому потрібне постійне різнопланове, багаторівневе, різноманітне навчання, яке б забезпечувало $з$ мінімальними витратами процес адаптації до швидких і різких змін.

Мета даної статті - виокремити особливості, характерні для навчання дорослих за андрагогічною моделлю; окреслити основні дії, операції, функції тих, хто навчає, і тих, кого навчають; довести, що відповідне завдання досить складне, багатомірне і багатоаспектне.

Основна частина. Розглянемо зазначені проблеми у контексті пріоритетної концепції розвитку освіт(c) О. М. Хвисюк, В. Г. Марченко, О. М. Касьянова та ін. ньої галузі - неперервності, теоретично осмислюючи вітчизняний та зарубіжний досвід навчання дорослих.

Про освіту як процес, що відбувається впродовж усього життя людини, накопичено чимало наукових ідей учених різних галузей наукового пізнання: філософії, педагогіки, психологічної соціології тощо, починаючи 3 часів Платона.

Теоретичну основу дослідження становлять праці українських та зарубіжних учених із проблем: філософії неперервної освіти (В. П. Андрущенко, І. А. Зязюн, В. Г. Кремень, В. С. Лутай); особистісно орієнтованої парадигми освіти (А. Маслоу, К. Роджерс, С. І. Подмазін, В. О. Сухомлинський, О. Я. Савченко, I. С. Якиманська); гуманізації освіти від стародавніх часів до сучасності (Конфуцій, Сократ, Аристотель, Сенека, Т. Кампанелла, А. С. Макаренко, В. О. Сухомлинський, Ш. О. Амонашвілі, В. І. Лозова, Г. В. Троцко, М. Ю. Красовицький та ін.); післядипломної педагогічної освіти (В. І. Бондар, Л. І. Даниленко, Г. В. Єльникова, С. В. Крисюк, В. І. Маслов, Н. Г. Протасова, О. П. Тонконога, В. С. Пікельна, С. О. Сисоєва, П. В. Худомінський та ін.); оптимізації навчання й розвитку особистості (Л. В. Занков, М. М. Поташнік, Г. І. Щукіна); андрагогіки (М. Ноулз, А. О. Деркач, С. І. Змєйов, Н. В. Кузьміна, Б. В. Гадзецький, Н. Г. Протасова, О. М. Пехота та ін.).

Зупинимося на особливостях навчання дорослих. 3 точки зору на означену проблему, вважаємо за необхідне розкрити одне із фундаментальних понять 
дидактики - “навчання”, яке до цього часу не має єдиного трактування.

Навчання розглядається як цілеспрямований процес взаємодії між учителем і учнями 3 метою їх розвитку і виховання [3].

Під навчанням розуміють: “цілеспрямований педагогічний процес організації й стимулювання активної навчально-пізнавальної діяльності учнів, спрямований на оволодіння науковими знаннями, уміннями, навичками, розвитку творчих здібностей, світогляду й морально-естетичних поглядів і переконань" (І. Ф. Харламов); “процес взаємодії учителя і учня, у результаті якого забезпечується розвиток учня" (Н. В. Бордовска, А. А. Реан); “цілеспрямований процес передачі засвоєння знань, умінь, навичок i способів пізнавальної діяльності людини” (С. У. Гончаренко); “спільна цілеспрямована діяльність учителя і учня, у ході якої здійснюється розвиток особистості, їі освіта і виховання” (В.В.Краєвский); “стосовно навчання у вищій школі - це цілеспрямована взаємодія викладача і студента, у процесі якої здійснюється формування ціннісного і творчого ставлення до оточуючої дійсності, відбувається загальний розвиток” (В. І. Лозова); “навчання педагогів у системі підвищення кваліфікації розглядають як співтворчість викладачів і слухачів" (Г. І. Сущенко).

Аналіз різних визначень дає підставу виокремити ключове слово, яке об' єднує погляди різних авторів на навчання - це поняття “діяльність”, завдяки якій людина існує, взаємодіє із соціумом, впливає на природу, людей, розвивається.

Таким чином, навчання є основним видом діяльності людини, способом іï існування, супроводжує людину майже все життя. Звичайно, навчальна діяльність обумовлена низкою чинників, які, безумовно, впливають на характер, принципи ії організації, але перш за все вона визначається антропологічними, тобто фундаментальними даними наук про людину, які мають суттєві відмінності у різному віці. Акцентуючи увагу на діяльність того, хто навчається, американський учений Р. М. Сміт виділяє шість аспектів навчання дорослих, а саме:

- навчання відбувається протягом усього життя;

· навчання - це природний і особистісний процес;

· навчання включає в себе зміни в людині, яка навчається;

• навчання пов'язане з розвитком особистості;

· навчання пов'язане 3 досвідом людини та ії діяльністю;

· у навчанні є також своя інтуїтивна сторона, тобто воно може проходити частково на підсвідомому рівні.
Російський дослідник навчання дорослої людини С. І. Змєйов висловлює думку, що “сьогодні у життєвому циклі людини розрізняють три основні етапи, які мають суттєві відмінності та впливають на організацію процесу навчання людини: юність, дорослість (зрілість) і старість" [4]. Оскільки людина змінюється протягом життя, значить і навчається вона у певні роки по-різному.

Довгий час, приблизно до середини ХХ століття, сферою уваги науковців і практиків було переважно навчання лише дітей та молоді. Так, до 1960-х років суспільство не вимагало від кожної людини систематичного, цілеспрямованого неперервного навчання впродовж усього життя. Існувала думка, що достатньо детально дослідити процеси навчання в дитячому, найбільш сприятливому для навчання, віці та екстраполювати ці закономірності на весь життєвий процес навчання людини. Проте дослідники проблем навчання дорослих запевняють, що принципи навчання, які напрацьовані людством та розкриті у педагогіці, не завжди ефективні для навчання дорослих.

Проблема освіти, навчання та виховання дорослих постала в другій половині минулого століття у зв' язку з вступом людства в індустріальний період розвитку, коли знання, уміння, праця дорослих людей стали вкрай необхідними. Відомий французький діяч у сфері неперервної освіти П. Лангран запевняє, що "майбутнє освіти, якщо розглядати її в цілому, і ії здатність до оновлення залежить від розвитку освіти дорослих" [5].

Більшість педагогів вважає, що навчання - двостороній процес, який включає дві нерозривно пов’ язані діяльності - це діяльність учителя, тобто викладання, та діяльність учня - учіння (Б. Т. Лихачов, С. І. Змєйов, В. І. Лозова, Г. М. Коджаспірова та ін.).

Зміна методології освіти наприкінці ХХ століття, а також і освітньої парадигми змушує науковців і практиків активізувати пошук оптимальних умов для організації двостороннього процесу взаємопов'язаних діяльностей: викладання, управління навчальною діяльністю (учіння), тобто взаємодії тих, хто навчає, і тих, кого навчають.

У Міжнародній стандартній кваліфікації освіти (МСКО) у ст. 9 поняття "учіння" визначається як “будь-яке поліпшення в поведінці, інформації, знаннях, розумінні, ставленні, цінностях та вміннях”. В Українському педагогічному словнику (1997 рік) учіння характеризується як цілеспрямований процес засвоєння учнями знань, оволодіння різноманітним суспільним досвідом у його узагальненому вигляді. Аналогічно поняття “учіння” розглядається в Тезаурусі для освітніх систем у Європі. 
У педагогічному словнику Г. М. Коджаспірової учіння трактується як “особливим чином організоване пізнання; пізнавальна діяльність тих, хто навчається, направлена на оволодіння сумою знань, умінь і навичок, способів навчальної діяльності” [6].

У середині XX століття стала відчутною необхідність у створенні своєї спеціальної науки про навчання дорослих. До цього часу в різних країнах світу був накопичений великий досвід практичної організації освіти дорослих, емпіричних даних про особливості навчання та його своєрідність.

Значний внесок у розвиток освіти дорослих зробили видатні американські вчені Дж. Д'юі та Е. Ліндсман, ідеї яких лягли в основу філософії навчання дорослих.

Аналіз наукових розвідок вітчизняних та зарубіжних учених стосовно навчання дорослих свідчить:

- про зростання значимості післядипломної освіти для окремої особистості;

- про те, що післядипломне навчання має свою специфіку, яка обумовлена особливостями тих, хто навчається;

· про звернення вчених до андрагогіки.

Отже, у середині минулого століття (1950-1970-х роках) почала розвиватися нова наукова дисципліна у сфері освіти - андрагогіка як самостійна наука. Основоположниками андрагогіки $є$ американські вчені М. Ноулз і Р. Сміт, англійський учений П. Джарвіс, німець Ф. Пьоггелер, голландець Т. Тен. Хаве, поляк Л. Турос та ін.

Сьогодні ця наука проходить стадію кінцевого формування, а тому у визначенні основних положень, закономірностей, факторів, причин, етапів зародження та розвитку андрагогіки виникають різні, навіть спірні погляди (точки зору).

Польський учений Л. Турос вважав, що андрагогіка - це наука про мету, походження, умови, результати та закономірності свідомої іцілеспрямованої організованої освіти й виховання дорослих, а також самоосвіти й самовиховання. Один із дослідників навчання дорослихП. Форте визначає андрагогіку як "науку про формування людини протягом усього життя”. На думку Б. В. Гадзецького, андрагогіка - це нова галузь знань i науки про освіту. За Г. Н. Протасовою, андрагогіка-це теорія навчання дорослих, яка виходить із того, що мета сучасного підходу до освіти полягає у сприянні розвитку та збагаченню цілісності особистості, прояву їі самобутності, актуалізаціїїі прихованих здібностей.

Андрагогіка, як запевняє С. І. Змєйов, - це педагогіка дорослих, одна 3 педагогічних наук, яка займається дослідженням проблем освіти, самоосвіти й вихо- вання дорослих [7]. Американський учений М. Ноулз називав андрагогіку мистецтвом $і$ наукою допомоги дорослим у навчанні, “системою положень” про дорослих, які навчаються, яку потрібно застосовувати диференційовано “до різних дорослих людей залежно від ситуації”.

Отже, андрагогіка (від грецької andros - доросла людина), як теорія навчання дорослих, інтегрує знання про специфіку навчання дорослих з урахуванням віку, освітніх та життєвих навичок, реалізованих та прихованих здібностей, можливостей, індивідуальних особливостей.

Концептуальні положення андрагогіки узагальнив вітчизняний вчений Б. Дьяченко, який запевняв, що:

· провідна роль у процесі навчання належить тому, хто навчається;

- процес навчання спрямовується на задоволення особистісних запитів слухачів;

- навчання стимулює потребу слухачів у професійному розвитку [8].

Методологічні засади андрагогіки педагога складає посилення особистісної зорієнтованості процесу навчання, активізація творчого потенціалу фахівців, ïх професійного зростання та ін. При цьому сам дорослий відіграє величезну роль у формуванні мотивації та визначенні мети навчання, відповідно до його потреб щодо вивчення чогось та вирішення конкретних життєвих проблем. 3 точки зору андрагогіки завдання викладача зводиться до підтримки, заохочення розвитку дорослого та надання допомоги у визначенні об'єму навчання, пошуку інформації. Саме він створює необхідні сприятливі умови для навчання дорослої людини. Перш за все, викладач турбується про створення позитивного психоемоційного клімату, комфортних фізичних умов навчання, які характеризуються взаємною повагою учасників процесу навчання, емпатичним ставленням один до одного. Він відповідає за науково-методичне забезпечення навчального процесу відповідно до програми, яку педагог обирає сам.

Підтримуємо точку зору вчених, застосування діалогічних методів у навчанні дорослих, тобто взаємодія дорослого - викладача та дорослого - слухача $€$ основою андрагогічної моделі (Б. Ананьєв, С. Болтівець, С. Змєйов, Ю. Кумоткін, Н. Протасова та ін.). Звідси, особливого значення набуває консультування, яке будується на партнерській взаємодії, за індивідуальною формою роботи з дорослими.

Таким чином, за андрагогічною моделлю навчання дорослий стає суб'єктом навчання, йому надається можливість працювати за суб' єкт-суб'єктною 
взаємодією, коли кожен є активним учасником в організації процесу навчання, має право на власну думку та критично приймати різні точки зору, задавати питання та поважати думки інших тощо. Завдяки андрогогічному підходу викладач з носія інформації перетворюється на співавтора навчального процесу, стає співучасником здобуття інформації та одним із джерел іiі отримання. Викладач у андрагогічній моделі навчання виступає в ролі організатора взаємодії, консультанта, експерта.

Висновок. На нашу думку, традиційна система післядипломної освіти в тому вигляді, у якому вона до цього часу існує, себе вичерпала і еволюційним шляхом, шляхом внутрішньої модернізації (перетворення) повинна перейти у якісно новий стан, відповідно до вимог сучасності. Сподіваємось, що андрагогічні підходи до навчання дорослих сприятимуть цьому процесу, коли провідна роль належить дорослому, а він сам прагне до самореалізації, самостійності, самоуправління; життєвий професійний соціальний досвід є джерелом для навчання, як самого дорослого, так і його колег; сам процес навчання будується як взаємодія на різних його етапах від планування до корекції.

\section{Лiтература}

1. Исламшин Р. А. Андрагогика: историко-педагогический процесс и языковая личность XXI века : учебное пособие / Р. А. Исламшин, В. Ф. Габдулхаков. - Москва-Воронеж : Изд-во НПО “МОДЭК”, 2005. -286 с.

2. Василькова Т.А. Андрагогика : учебно-методическое пособие / Т. А. Василькова.-М. : ВНПЦ профориентации, 2002. -136 c.

3. Громкова М. Т. Андрагогика: теория и практика образования взрослых: учебное пособие / М. Т. Громкова. М. : ЮНИТИ-ДАНА, 2005. - 495 с. - (Серия “Высшее профессиональное образование: Педагогика").

4. Змеев С. И. Основы андрагогики : учебное пособие для вузов / С. И. Змеев. - М. : Флинта: Наука, 1999. - 152 с.

5. Змеев С. И. Андрагогика: основы теории, истории и

технологии обучения взрослых / С. И. Змеев. - М. : ПЕР СЭ, 2007.-272 c.

6. Ломтева Т. Н. Андрагогика в контексте гуманистической образовательной парадигмы / Т. Н. Ломтева. - Ставрополь : Изд-во СГУ, 2001. - 340 с.

7. Педагогический энциклопедический словарь / гл. ред. Б. М. Бим-Бад ; редкол. : М. М. Безруких, В. А. Болотов, Л. С. Глебова и др. - М. : Большая Российская энциклопедия, 2003. $-528 \mathrm{c}$.

8. The Adult Learner:The Definitive Classic in Adult Education and Human Resource Development / M. S. Knowles, E. E. Holton, R. A. Swanson. - 6th edition. London, New York: ELSEVIER Butterworth Heinemann, 2005. $-378 \mathrm{p}$. 